\title{
COST OF DRUGS MANUFACTURED BY THE UNIVERSITY HOSPITAL - ROLE OF THE CENTRAL PHARMACY
}

\author{
Marcia Lucia M. Marin, Cleuber E. Chaves, Antonio C. Zanini, Joel Faintuch, \\ Daniel Faintuch and Sonia L. Cipriano
}

MARIN MLM et al. - Cost of drugs manufactured by the University Hospital - role of the Central Pharmacy. Rev. Hosp. Clín. Fac. Med. S. Paulo 56(2):41-46, 2001.

The hospital pharmacy in large and advanced institutions has evolved from a simple storage and distribution unit into a highly specialized manipulation and dispensation center, responsible for the handling of hundreds of clinical requests, many of them unique and not obtainable from commercial companies. It was therefore quite natural that in many environments, a manufacturing service was gradually established, to cater to both conventional and extraordinary demands of the medical staff. That was the case of Hospital das Clinicas, where multiple categories of drugs are routinely produced inside the pharmacy. However, cost-containment imperatives dictate that such activities be reassessed in the light of their efficiency and essentiality.

Methods: In a prospective study, the output of the Manufacturing Service of the Central Pharmacy during a 12-month period was documented and classified into three types. Group I comprised drugs similar to commercially distributed products, Group II included exclusive formulations for routine consumption, and Group III dealt with special demands related to clinical investigations.

Results: Findings for the three categories indicated that these groups represented $34.4 \%, 45.3 \%$, and $20.3 \%$ of total manufacture orders, respectively. Costs of production were assessed and compared with market prices for Group 1 preparations, indicating savings of $63.5 \%$. When applied to the other groups, for which direct equivalent in market value did not exist, these results would suggest total yearly savings of over 5100000 US dollars. Even considering that these calculations leave out many components of cost, notably those concerning marketing and distribution, it might still be concluded that at least part of the savings achieved were real.

Conclusions: The observed savings, allied with the convenience and reliability with which the Central Pharmacy performed its obligations, support the contention that internal manufacture of pharmaceutical formulations was a cost-effective alternative in the described setting. hospital.

DESCRIPTORS: Cost. Cost-containment. Hospital pharmacy. Drug manipulation. Drug industrialization. University

Large university-affiliated tertiary hospitals, like Hospital das Clinicas, are service-related institutions responsible for the provision of complex health assistance to many of the sickest segments of the population. At the same time, they participate in teaching and training responsibilities for graduate and postgraduate students and fellows, and are involved with multiple clinical and experimental investigation protocols.

These roles represent a radical departure from the historical origins of nosocomial units as organizations for charity, hospitality, and beneficence

From the Pharmacy Division, Hospital das Clinicas, Faculty of Medicine, University of São Paulo. maintained by religious orders or wealthy donors, and not responsive to anybody in particular except to the conscience and moral principles of its governing board, towards a modern economic unit concerned with rational organization, lean structure, specialized personnel, technical expertise, external audits, cost-efficient performance, and high productivity ${ }^{1}$. All such aspects 
have a bearing on the functions of the Central Pharmacy, especially when it is engaged in manufacture in addition to dispensation of medicines. In such circumstances it must adapt itself to new and demanding challenges, and fulfill all the expectations of a modern commercial and industrial department, in addition to its traditional activities.

Still, teaching hospitals are not typical businesses, in the sense that economical considerations are essential but not always of paramount importance in the decision-making process. Their merchandise is human life, which is priceless; their shareholders in a larger sense are the entire community they are serving. Possibly more numerous legal, moral, and professional codes and regulations apply to their routines than to any other human endeavor, and many of these have the potential for interfering with financial results.

The Manufacturing Service of the Central Pharmacy is not free from these constraints; scientific, social, and ethical considerations are often as important determinants of its workload as are technical and economical duties with regard to hospital departments and needs of internal and external patients.

Within the sometimes opposing contexts of utmost cost-efficiency expected from modern organizations and large expenditures dictated by unprofitable humanistic responsibilities, a conflict of interests could arise within the pharmacy. Indeed many controversial views of its future are currently debated $^{2-4}$. The doubts become even more serious when one considers that preparation of pharmaceutical formulations is not an obligatory role of the hospital pharmacy nowadays, since external companies could be requested to supply such items, rendering its resources free for other purposes.

Aiming to contribute to the discussions about the place of drug manipu- lation and industrialization in a modern pharmacy, a prospective cost-evaluation study was done during a 12month period, covering the entire physical and economical manufacturing output of the Central Pharmacy. These results were compared with the alternative of purchasing the same products from commercial sources, whenever available.

\section{MATERIALS AND METHODS}

Total drug deliveries of medicines manufactured by the Central Pharmacy of Hospital das Clinicas were documented in the period of January $1^{\text {st }}$ December $31^{\text {st }}$, 1999 , according to unit type and pharmaceutical category. This output was stratified in three groups: Group I - Pharmaceutical preparations ordinarily made by the Pharmacy similar to commercially distributed products; Group II - items routinely manufactured with exclusive formulations, not available in the market; Group III - new and experimental drugs, mixtures or presentations expressly destined to approved clinical protocols.

Methods included systematic computing of all orders processed by the Central Pharmacy in the year of 1999, classified as mentioned before, along with preliminary cost estimation, both of internal expenditures, and of corresponding market price.

Cost calculation - Commercial items were entered in accordance with published manufacturer's lists, updated for December 31, 1999. The same date was considered for internal costs, divided into 4 categories: a) Raw materials; b) Packaging ; 3) Materials consumed during industrial or manipulation processes; 4) Approximate labor costs. All values were converted into US dollars.

These amounts represent main direct and indirect expenditures, and exclude other costs (financing, taxes, commercialization, profits, and miscellaneous overheads).

\section{Preliminary considerations}

Over the years the Manufacturing Service has established 7 different lines, geared to the principal needs of the institution: small-volume parenterals (SVP), large-volume parenterals (LVP), oral solutions (OS), non-oral solutions (NOS), hemodialysis fluids (HDF), solid items (SI), and semi-solid products (SSP). Numerically, the principal demand is for solid items (oral drugs in the form of pills, tablets, and capsules), but it is either small-volume parenterals (injectable drugs) or large-volume parenterals (principally parenteral nutrition mixtures) that usually embody the largest economical value. In the present study, the same lines are adopted in the calculation of total production.

\section{RESULTS}

A grand total of 340 types of items were manufactured by the Manufacturing Service during the analyzed period. Only 117 had similar commercially available preparations $(34.4 \%)$, whereas 154 were exclusive formulations (45.3\%). Moreover, 69 requests for investigations were delivered $(20.3 \%)$, all related to unusual and non-marketed drugs, fluids, or presentations. The discrimination of the numerical and financial equivalent for each of these modalities is shown in tables 1,2, and 3, as well as in charts 1,2 , and 3 .

Commercial value was directly transcribed from public lists with regard to components of Group I. Group II and III items defied attempts to obtain a faithful quotation; therefore, the differences in prices were primarily calculated for Group I. The total value of US $\$ 3,039,953.86$ represents a 
Table 1 - Products similar to commercial formulations (Group I).

\begin{tabular}{lrrr}
\hline Modality & \multicolumn{1}{c}{ Units } & Internal cost (US\$) & Commercial price (US\$) \\
\hline Small volume parenterals & $1,977,333$ & $560,825.15$ & $2,672,654.92$ \\
Large volume parenterals & 24,803 & $91,500.89$ & $69,277.55$ \\
Oral solutions & 118,913 & $87,895.28$ & $135,138.32$ \\
Non-oral solutions & 70,469 & $132,128.47$ & $143,388.12$ \\
Hemodialysis fluids & 42,920 & $280,229.79$ & $559,592.65$ \\
Solid items & $13,904,694$ & $537,978.68$ & $1,081,046.96$ \\
Semi-solid products & 32,364 & $55,019.49$ & $124,433.08$ \\
Total & $16,171,496$ & $1,745,577.74$ & $4,785,531.60$ \\
\hline
\end{tabular}

Manufactured items that were also available in the market are listed.

Table 2 - Industrial output of exclusive formulations (Group II)*.

\begin{tabular}{lrc}
\hline Modality & \multicolumn{1}{c}{ Units } & Internal cost (US\$) \\
\hline Small volume parenterals & 554,890 & $225,987.38$ \\
Large volume parenterals & 50,161 & $443,390.69$ \\
Oral solutions & 14,600 & $23,164.04$ \\
Non-oral solutions & 30,470 & $124,086.83$ \\
Hemodialysis fluids & & \\
Solid items & $3,233,752$ & $166,090.98$ \\
Semi-solid products & 36,759 & $99,446.41$ \\
Total & $3,920,632$ & $1082,166.33$ \\
\hline
\end{tabular}

(*) No market value could be assessed for this category.

Routinely produced exclusive items are included.

Table 3 - Orders for research projects (Group III)*.

\begin{tabular}{lrc}
\hline Modality & \multicolumn{1}{c}{ Units } & Internal cost (US\$) \\
\hline Small volume parenterals & 15,406 & $24,311.80$ \\
Large volume parenterals & 4,230 & $33,185.18$ \\
Oral solutions & - & - \\
Non-oral solutions & 4,726 & $11,739.19$ \\
Hemodialysis fluids & 25 & 271.58 \\
Solid items & 436,582 & $31,895.33$ \\
Semi-solid products & 517 & $1,469.47$ \\
Total & 461,486 & $102,872.55$ \\
\hline
\end{tabular}

(*) Commercial value not available for comparison.

Non-routine requests experimental mixtures are displayed.

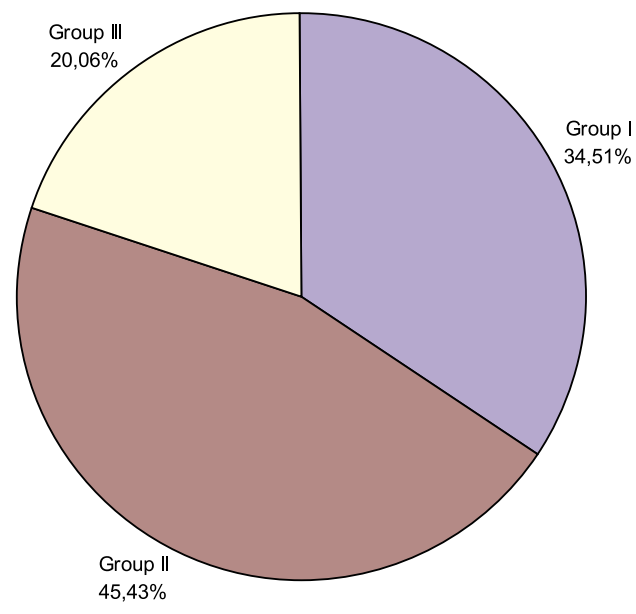

Chart 1 - Percentage distribution of drug categories.
$63.5 \%$ savings with regard to external purchase. If by hypothesis the same savings were achieved in all groups (total amount $\$ 2,930,616.63$ ), over $\$ 5,100,000.00$ would have to be credited to the Manufacturing Service during the studied period.

\section{DISCUSSION}

The ultimate goal of nosocomial institutions, including the pharmacy, which is a central part of these organizations, is to improve sick people's lives through therapeutic interventions to reduce morbidity, combat mortality, and foster quality of life. Modern economic realities mandate that this is to be accomplished in the least expensive way.

Employing a simplified economic analysis in the pharmacy, one can define inputs, outputs, and productivity, which is the relationship between the former and the latter. The investment or input encompasses such factors as facilities, specialized equipment, personnel, administrative costs, drugs and other materials that are purchased or utilized in order to properly operate a central pharmacy with manipulation responsibilities. The direct result should be a profitable balance sheet with high productivity and few losses or unnecessary expenditures. However, all these are worthless if they are not compatible with good quality of care and high standards of medical assistance, which are more difficult to mea- 


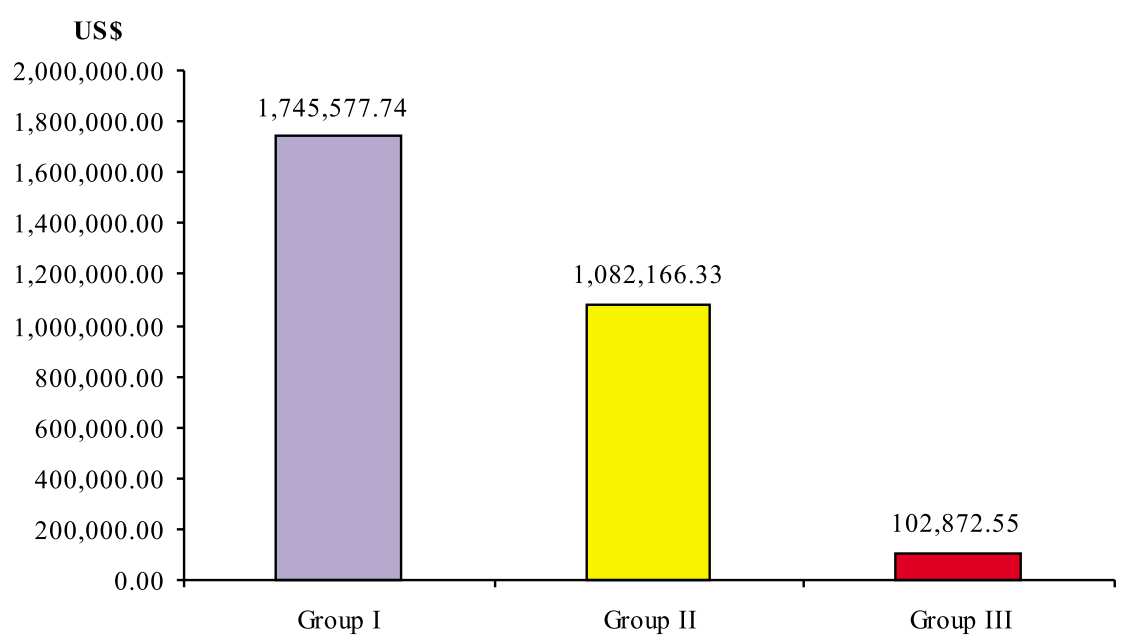

Chart 2 - Estimated cost of manipulated products.

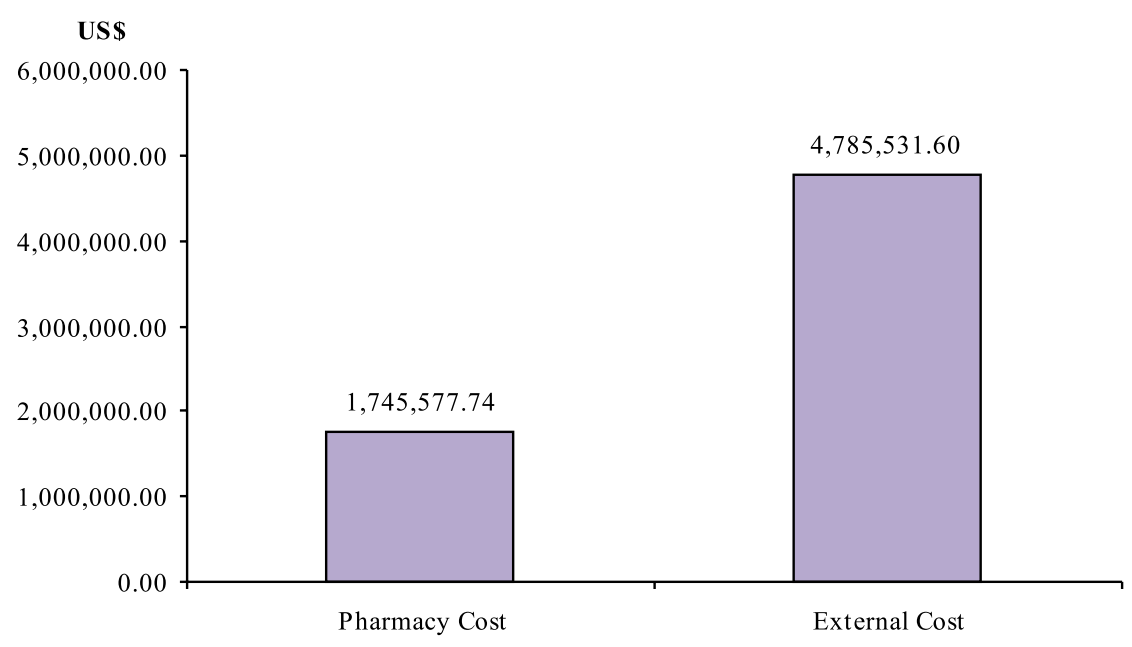

Chart 3 - Comparative analysis of internal versus market costs (Group I).

sure because they are not easily translated to money, and their impact tends to become clearly visible only on a long term basis.

In recent years, medical outcomes have evolved into a sub-specialty, which attempts to quantify these intangibles that were previously alluded to ${ }^{5,6}$. Morbidity, mortality, functional changes, psychosocial results, scientific achievements, and patient and community satisfaction all build the reputation, prestige, and esteem of the institution, which are perhaps the best yardstick for its performance and total value. A similar view was provided by Lohr $^{7}$, who devised some years ago the five services. Obviously, only the very latest advances in pharmacological and clinical investigation should be delivered, and personnel should have expertise in all fields of drug manipulation and therapy. And yet, how these aims can possibly be reached within an environment of cost-containment, and who should financially support them, is rarely given sufficient consideration ${ }^{1-3}$.

Some preventive and corrective steps are sensible and should always be adopted, namely those related to rationalization of pharmacy resources. Areas of both overutilization and underutilization of equipment and personnel are economically inconvenient and should be identified to adjust production lines to quantitative demand. In the first case, excessive consumption of certain drugs may lead to delays in production, poor quality control, and increased stress for technicians and pharmacists. The opposite situation (underutilization) will represent a wastage of time and money, or even worse, may deprive patients of needed services because of poor allocation of available resources ${ }^{3,6}$.

Optimization of all methods and procedures-removing inefficiencies and bottlenecks, abolishing unnecessary paperwork, and rationalizing fluxes of people and materials - is an indisputable maneuver for streamlining output of pharmaceutical products. This optimization contributes to increased productivity and may save major amounts of money. In the specific situation of the Central Pharmacy of Hospital das Clinicas, ideal conditions for utilization of resources and improvement of methods and procedures do not always exist, due to technical and administrative limitations inherent in public institutions. Still, there is an ongoing effort to update systems, consider new production routines, and overcome barriers that might hamper drug output or jeopardize quality of the end products ${ }^{1-3}$. 
True final costs of pharmacy services are difficult, if not impossible to ascertain. In private organizations, they are eventually defined by the market, in the sense that what is charged is as much (or as little) as competitors and consumers will allow. The number of factors involved in pricing is enormous, including many types of overhead or general expenses, hidden or "black box" items such as provision for future expansion or renovation, and coverage for bad debts or failed reimbursement, plus distribution costs, which are very pertinent in the present study ${ }^{8,9}$.

Indeed, all internal values here displayed (Tables 1, 2, and 3) embody only principal direct and indirect expenditures, and explicitly exclude commercialization costs, which can reach very significant levels. Advertisement, marketing, delivery, sales taxes, profits, and commissions for the sales chain often double the initial estimates for drug prices. In this setting, it is not unreasonable to imagine that most of the savings here achieved could simply correspond to the fact that internal production instead of external purchase was the selected alternative, thus bypassing the mentioned distribution charges.

Nevertheless, the fact is that the investments for establishing and maintaining the Manufacturing Service of the Central Pharmacy of Hospital das Clinicas have long been completed and the unit is in full operation. Even if this was not reason enough for using it, the current demonstration that approximately two/thirds of its output deal with exclusive formulations or pharmacological agents essential for clinical in- vestigations should justify its continuing activities. These products have no immediate substitute in the market, and it is expected that the institution would have to pay a substantial surcharge, and probably incur great delays and logistic problems, to order them elsewhere.

A university-affiliated hospital does not have the obligation for spending a share of its budget to sustain advertisement, marketing, and sales teams of external purveyors, and perhaps not even commercial hospitals should entertain this possibility, when pharmaceutical items can be successfully provided by internal manipulation. The opposite hypothesis would only make sense if estimated internal costs came close to market prices, thus suggesting that total real costs were equal to, or greater than external ones, especially within a context of aggressive purchasing policies, which would probably wipe out any remaining differences ${ }^{3,4}$.

The temptation to abolish manufacturing responsibilities cannot be underestimated in busy and understaffed services, especially because this is not a fundamental activity for the hospital pharmacy. According to modern theories of business management, non-core endeavors are best redistributed to specialized third-parties, who in principle can do it better and cheaper.

Under the conditions of this project, only a few answers can be anticipated for these complex issues, and future studies will be mandatory. Yet, in the light of the composition, quantity, nominal cost, and estimated external cost of principal categories of drugs fabricated by the Manufacturing Service, it stands to reason that the present system has been doing an outstanding job. It has catered not only to standard requests but principally to exclusive and out-of-themarket demands of a large, universityassociated hospital, while at the same time achieving important savings. The need for future changes and adjustments cannot be ruled out; indeed progress is always welcome, as long as it is preceded by careful assessment of expected gains and possible losses ${ }^{1,3,4,8}$.

\section{CONCLUSIONS}

The analysis of manipulation of pharmaceutical formulations by the Central Pharmacy has permitted the following conclusions:

1) The majority of preparations manufactured by the Central Pharmacy corresponded to drugs without similar preparations available commercially: in addition to other exclusive items related to clinical studies, they represented about twothirds of total output;

2) Direct comparison of internal and external costs confirmed savings of $63.5 \%$ for commercially available formulations. If computed for the entire production, a yearly balance of over US \$5000 000 in favor of the hospital would have been reached;

3) In the light of these findings, there are reasons to believe that industrial manipulation of drugs by the Central Pharmacy has been a beneficial and cost-effective process.
MARIN MLM e col. - Custo de medicamentos produzidos pelo Hospital Universitário, papel da Farmácia Central. Rev. Hosp. Clín. Fac. Med. S. Paulo 56(2):41-46, 2001.
A Farmácia Hospitalar em instituições avançadas e de grande porte evoluiu de uma simples unidade de armazenamento e distribuição, para um centro de manipulação altamente especi- alizado, responsável pelo processamento de centenas de requisições clínicas, muitas delas únicas e não disponíveis de fontes comerciais. Foi perfeitamente natural portanto que em 
muitos ambientes, um Serviço Industrial fosse gradualmente estabelecido, visando responder a demandas tanto convencionais como extraordinárias da equipe médica. Tal foi o caso do Hospital das Clínicas, onde múltiplas categorias de fármacos são rotineiramente elaboradas nas dependências da Farmácia. Entretanto, imperativos de contenção de gastos determinam que tais atividades sejam reajuizadas sob o prisma de sua eficiência e essencialidade.

Métodos: Num estudo prospectivo, a produção do Serviço Industrial da Farmácia Central durante um período de 12 meses foi documentada, e classificada em três modalidades. O Grupo I abrangia medicamentos similares a outros fornecidos comercialmente, no Grupo II foram listadas formulações de composição exclusiva, e finalmente o Grupo III espelhava pedidos especiais voltados para investigações clínicas.

Resultados: Os achados das diversas categorias assinalaram que $34,4 \%$, $45,3 \%$ e $20,3 \%$ dos medicamentos elaborados correspondiam a estes três grupos, respectivamente.Os custos industriais foram calculados para os fármacos do Grupo I e comparados com valores de mercado, chegando-se a uma economia de $63,5 \%$.Quando extrapolada para os outros dois grupos, relativamente aos quais não se contava com preços comerciais diretamente equivalentes, atingiu-se uma estimativa superior a 5100000 dólares de economia durante um ano de operação. Mesmo levando-se em conta que tais contas deixaram de lado muitos custos, notavelmente aqueles subordinados à comercialização e distribuição, foi lícito concluir que pelo menos parte da economia citada era verdadeira.

Conclusões: A economia observada, em combinação com a eficiência e confiabilidade com que a Farmácia desempenhou suas obrigações, vieram ao encontro do ponto de vista de que a manufatura interna de drogas foi uma alternativa vantajosa sob o prisma de custos, no contexto descrito.

DESCRITORES: Custo. Contenção de custo. Farmácia hospitalar. Manipulação de drogas. Industrialização de drogas. Hospital Universitário.

\section{REFERENCES}

1. CARBONELL JG - Esquema conceptual de costo por producto hospitalario. Tecnica Contable 1989;41:143-154.

2. FRENKEL M - Public attitudes and expectations in the escalation of health care costs. Perspec Biol Med 1989; 32:257-271.

3. BOYKO WLJR, YOURKOWSKI PJ, IVEY MF et al. - Pharmacist influence on economic and morbidity outcomes in a tertiary care teaching hospital. Am J Health-Syst Pharm 1997; 54:1591-1595.

4. SUNDBERG JÁ - Manipulação magistral na farmácia hospitalar. Int J Pharmac Compounding 2000 (Brazilian Ed) 2:42-47.

5. EPSTEIN AM - The outcomes movement: Will it get us where we want to go ? New Eng J Med 1990;323:266-270.
6. PARK RE, BROOK RH \& KOSECOFF J - Explaining variations in hospital death rates: Randomness, severity of illness, quality of care. J Amer Med Assoc 1990;264:484-490.

7. LOHR KN - Outcome measurement. Concepts and questions. Inquiry 1998; 25(Spring):37-50.

8. WERMELING DP, PIECORO LT \& FOSTER TS - Financial impact of clinical research on a health system. Am J Health-Syst Pharm 1997; 54:1742-1751.

9. TWOMEY PL \& PATCHING SC - Cost-effectiveness of nutritional support. J Parent Ent Nutr 1985; 9:3-10.

Received for publication on October 17, 2000 